\title{
Cross Cultural Management: Hybridization of Dutch - Indian Work Practices in Geographically Distributed IT Projects
}

\author{
Alfons van Marrewijk \\ VU University Amsterdam
}

\begin{abstract}
Business anthropologists can play an important role in the debate on cross cultural management. Unfortunately, studies on cross-cultural management are dominated by cultural value models, such as those described by Hofstede (1980), Adler (1986), Hall (1976) and Trompenaars (1993). These single and multiple dimensional models have narrowed the debate on cross-cultural management. To move away from these cultural values studies and open up new directions of cross-cultural research this paper focuses on the question of which collaborative practices emerge in the interface of Western and Indian branches of four Multinational IT Service Providers (MITSP); IBM, Accenture, Atos Origin and Philips. As a consequence of Global Sourcing strategies, front and back office employees in MITSP's are now collaborating in geographically distributed project teams in the development and maintenance of client software. The in-depth case study was executed in the Netherlands and in India in the period of 2005 to 2007. The findings suggest that all companies formally strive for synergy but in the daily cooperation between the project teams power struggles and ethnocentric strategies dominate. The new cultural practices that emerge are a reflection of these power struggles between the Dutch and Indian project teams.
\end{abstract}

\section{INTRODUCTION}

Increasingly, employees in Western offices of Multinational IT Service Providers (MITSP) collaborate with their colleagues in Indian branches as MITSP's are locating their IT software development, testing and maintenance in emerging economies. In particular, India has become very popular for outsourcing (Carmel \& Tija, 2005; Krishna, Sahay, \& Walsham, 2004; Sahay, Nicholson, \& Krishna, 2003) because of; low wages; interesting investment climate; and qualified software developer (Budhwar \& Sparrow, 2002). Furthermore, Indian software developers speak English and often have extensive educational and cultural contact with the U.K (Krishna et al., 2004). Consequently, Indian software industry has witnessed unprecedented growth in the recent decade and is heading towards a dominant position in worldwide IT development and services (Budhwar, Varma, Singh, \& Dhar, 2006; Carmel \& Tija, 2005).

Given these developments, cross-cultural collaboration of employees in geographically distributed project teams has become an important topic in the success of global sourcing 
(Carmel, 1999; Dafoulas \& Macaulay, 2001; Krishna et al., 2004; Sahay et al., 2003; Staples \& Zhao, 2006). In many cases, cultural differences between Indian and Western offices hinder the efficient and successful execution of IT projects (Carmel, 1999; Carmel \& Tija, 2005). Consequently, a large part of the companies which started offshoring quit their activities (Matloff, 2005). To support these companies, business anthropologists help to improve business with cultural training (Gao, 2011), management (Marrewijk, 2010) and business communication (Tian, Lillis, \& Van Marrewijk, 2010).

Unfortunately, studies on cross-cultural collaboration in geographically distributed projects are dominated by cultural value models such as Hofstede (1980), Adler (1986), Hall (1976) and Trompenaars (1993) (f.e. Dafoulas \& Macaulay, 2001; Staples \& Zhao, 2006; Zwikael, Shimuzu, $\&$ Globerson, 2005). These single and multiple dimensional models have narrowed the debate on cross-cultural management (Morden, 1999) and received criticism for its singular focus on nation-state cultures and for the absence of power issues, sub-cultures, regional differences, ambiguity and situational behaviour (Jackson \& Aycan, 2006; Jacob, 2005; Lowe, 2002; Sackmann \& Friesl, 2007; Sackmann \& Phillips, 2004; Söderberg \& Holden, 2002). According to Jacob (2005) the criticized cultural value models cannot explain cultural heterogeneity, local management concepts and cultural imperialism.

Therefore, Jackson and Aycan (2006) make an appeal to cross-cultural researchers and managers to move away from cultural values research. In line with this, Lowe, More and Carr (2007), encourage cross-cultural researchers to employ bricolage in the context of local moralities, relationships and actionable outcomes. Their objective is to further the understandings of social and cultural phenomena over theoretical or methodological 'purity' and paradigmatic struggle (Lowe et al., 2007: 244). Others, such as Söderberg and Holden (2002) propose to develop a more dynamic model of cultural differences. They consider cultural differences to be the object and outcome of social interactions as much as any other forms of organizing within a multiple context of socially interdependent networks. Finally, Jackson and Aycan (2006) focus at social interaction between employees of culturally diverse backgrounds and study emerging local management models as well as new cultural practices. Their goal is to understand how particular management practices work in a certain context.

Given the discussion above, this paper addresses the question of which collaborative practices emerge in the interface of Western and Indian branches of MITSP's in IT projects teams, These teams are perceived as aggregations of employees temporarily enacting on a common cause (Hodgson \& Cicmil, 2006). The empirical findings presented in this paper are based upon an in-depth qualitative ethnographic study of four cases. The four studied cases are among the world's largest MITSPs; IBM, Accenture, ATOS Origin, and Philips. In-depth case studies provide a good understanding of daily work floor practices (Yin, 2003). In each case work practices in the front office in the Netherlands and in the back office in India have been studied. The research has been executed by a research team of 6 researchers in the period of 2005 to 2007 .

This paper is organised as follows. In the next section, a theoretical framework for studying collaborative practices is discussed. Then methodology used in this study is explained. Then, the findings of the study are presented. The findings are organised around a number of emerging practices related to managing time, communication, managing conflicts and negative feedback, and management style. The final section discusses the hybridization of cultural practices, and conclusions of this study are given. 


\section{CROSS CULTURAL COOPERATION IN IT PROJECTS}

Despite their criticisms, national cultural maps (f.e. Hofstede, 1980; Trompenaars, 1993) have helped to understand cultural differences between countries and to realise how an understanding of these differences is crucial in order to know what is appropriate management behaviour with regard to specific cultural contexts (Lowe, 2002). However, Peterson (2007) points out new directions for cross cultural research to overcome the misunderstandings in the cultural value perspective. Based upon an analysis of the anthropological roots of the value perspective he suggests, among others, to reconsider the concept of cultural boundaries and to include and better represent local culture. Indeed, cross cultural cooperation is increasingly based on boundary spanning networks as is the case with cross-cultural collaboration in geographically distributed project teams (Hasting, 1995). To perceive organizations and nation-states as homogeneous entities is out of touch with daily practices in a globalizing world (Söderberg \& Holden, 2002). In the case of India it is quite clear that the nation-state cannot be perceived as a homogeneous culture (Anisya \& Annamma, 1994; Chatterjee \& Pearson, 2001; Fusilier \& Durlabhji, 2001: 223; Singh, 1990: 75). India is a complex mosaic of many languages, cultures and religions (Gopinath, 1998). Furthermore, 'traditional' Indian values are changing in interaction with Western values (Anisya \& Annamma, 1994; Sahay et al., 2003; Sinha \& Sinha, 1990). It is therefore difficult to speak about the Indian identity. Sen (2005) emphasised the plural concept of the Indian identity, in which people have/make choices about what is significant to attach to their identity in distinct contexts.

To explore new directions for cross cultural research, Söderberg and Holden (2002) and Sackmann and Philips (2004) propose a social constructionist approach on studying the management of multiple cultures. The patterns of meaning are produced and reproduced and negotiated in the course of social interaction (Holden, 2002). Such an interpretative perspective focuses at processes of meaning, sense making and the social construction of culture by actors and come to a 'verstehen' of the constructed social reality (Weick, 1995). IT projects are then considered to be the object and outcome of social interactions as much as any other form of organizing within a context of multiple socially interdependent networks (Hodgson \& Cicmil, 2006). Such a social constructionist approach includes (a) power issues and situational behaviour and (b) hybridization of cultural practices (Jackson \& Aycan, 2006; Jacob, 2005; Lowe, 2002; Söderberg \& Holden, 2002). These concepts will be discussed here.

Ad. a) Cross-cultural cooperation does not take place in a power-free context. Nicholson (2001) included power and politics in their qualitative study of cross-cultural collaboration in a British - Indian software outsourcing. Strategies of tolerance, harmony, interdependence and synergy are instruments of dominant Western companies who want to maintain the status quo (Van Marrewijk, 2004). Strategies can be divided into three groups according to their similarities (within a certain group) (f.e. Adler, 1986; Holden, 2002; Schneider \& Barsoux, 1997). The first group of strategies concerns ethnocentric strategies which support the cultural dominance of home base companies. Unity, control by the headquarters of the parent company, home base values and home base management models characterize this group of strategies. The second group of strategies consists of polycentric strategies which stress the importance of the culture of a host country. The acceptance of cultural diversity, the relative autonomy of local branches and the minimization of cultural distance to the local market are all characteristics of this group of strategies. The final group consists of strategies which are combinations of the first two groups of strategies based on the assumption that cultural difference can be overcome or be 
constructively used for competitive advantage. Cooperation between head quarters and subsidiaries, the power relation between cooperating partners, and historical (ex) colonial relations influence successful cooperation (Van Marrewijk, 2004). In line with these findings, national identity and cultural differences have to be understood as the result of social interaction that is situational and can change over time (Jenkins, 2004). Consequently, national identity and cultural differences can be used strategically by a non-dominant partner to resist or even raise a blockade for cooperation (Ailon-Souday \& Kunda, 2003).

$A d$. b) The second topic of a social constructionist approach of cross cultural management includes the hybridization of cultural practices. New cultural practices emerge from social interaction between employees of culturally diverse backgrounds (Jackson \& Aycan, 2006). Shimoni and Bergmann (2006) developed a cultural hybridization approach which focuses at interactions, negotiations and mutual learning. In this approach, dichotomies of Western and local management are replaced by new hybrid work practices with sources of both local and Western culture (Shimoni \& Bergmann, 2006). This notion of a third culture has been worked out by Hannerz (1992). Examples of hybridization are found in Brannen and Salk (2000) who studied work practices in a German - Japanese strategic alliance and observed that Germans and Japanese had different attitudes toward working hours. New collaboration practices emerged as some of the German managers began to stay later at work while many of the Japanese worked fewer hours than they were accustomed to in Japan (Brannen \& Salk, 2000). Chevier (2003) identified three kinds of new cross-cultural practices of project managers which emerged from the collaboration of European R\&D groups. Firstly, cultural differences were managed drawing upon individual tolerance and self-control. Managers entered into a trial-and-error process coupled with relationship development. Thirdly, they capitalized on transnational corporate or professional cultures (Chevrier, 2003). Clausen (2007) used multi-contextual analysis to describe the dynamics and complexity of sense-making processes at the interface of meaning exchange in the collaboration between Danish and Japanese managers. In the collaboration between a Danish company and its alliance partner in the Japanese market a 'negotiated' culture emerged. Finally, Shimoni (2008) discusses emerging management styles in the collaboration of managers from Thailand, Mexico and Israel. Furthermore, in a study of Indian work practices Sapra (1995) warned managers of India's corporate sector to change the work culture of their employees and bring in stringent quality control in the manufacture of their products. Similarly, he warned managers of multinational corporations to understand and appreciate daily Indian work practices and show due respect for Indian culture and customs (Sapra, 1995). Kaker et.al. (2002) name corporations where Western and Indian management practices are hybridized. Hybridisation occurs when selective parts of a management system found effective in one culture are grafted onto the management system of a different culture (Jacob, 2005). Indian management is a fusion of western models and indigenous practices without hardly any uniformity throughout India (Anisya \& Annamma, 1994; Gopinath, 1998; Virmani, 2007). Virmani (ibid) calls this 'confusion' of the indigenous management caused by the need to adapt to different norms and practices to new and foreign concepts of management throughout history (Virmani, 2007: 287).

\section{Methodological Reflections}

Anthropological fieldwork methods are increasingly becoming popular in organization studies (Czarniawska, 1992; Schwartzman, 1993). These methods conform to a research strategy to describe, to interpret and to explain behaviour, meaning and cultural products of persons involved in a general limited field by direct data collection of researchers who are physically 
present (Yanow \& Schwartz-Shea, 2006). The major invention of anthropologists is the "doing" of ethnographic fieldwork by means of participant observation (Bate, 1997). For organizational fieldwork, the aim is to give an emphatic understanding of the daily activities of employees, to give the impression of having 'been there' and, to describe the connections of these employees with social, historical, cultural, political and economic processes in the organization (Bate, 1997). In contrast to the general perception of projects having a culture, they have to be perceived as cultures (Van Marrewijk, 2007). Rather than studying cultural phenomena of two partners as having impacts on a merging process, it is needed to study how these phenomena weave themselves into organizations (Holden, 2002: 54). In this "root" metaphor, organizations are modern tribes with artifacts, practices, values, multiple cultures, power relations, conflicts, and abnormalities (Martin, 2002). The interpretative perspective has increasingly received attention in organizational studies.

Data collection. To allow for systematic research a phased approach was used, starting with a pilot study held in 2005 by MA student Elsbeth Vogel-de Groot. For her thesis and under my direction, she interviewed nine Dutch and two Indian key informants in four leading companies in the Dutch ICT sector. In addition, she explored a literature review on Indian management. Analysing these data, we found that perceptions of time, communication and superiorsubordinate relationships were important elements in the cross-cultural cooperation involving Dutch and Indian employees in global IT projects. This provisional analysis has guided the study that is presented here.

In the second phase and under my supervision, a research team consisting of four Master's students approached the interested organizations IBM, Accenture, Atos Origin and Philips. Master's students themselves selected global projects within each case (Table 1). Field research was executed from June 2005 until December 2007. Topic interviews, in English and Dutch, were held with front and back office employees as well as management. In total, the research team conducted 39 interviews with Dutch front office managers and employees in the Netherlands and 51 interviews with Indian back office managers and employees (see Table 1). Almost all of the interviewed respondents were male, and $90 \%$ of respondents had previous international experience in other global projects. Typically, respondents were encouraged to talk about daily life on the work floor to obtain an insider's perspective in a given situation while following a certain topic format. Topic interviews benefit the systematic collection of data without losing flexibility and spontaneity (Ritchie \& Lewis, 2003). The interview questions focused on time, communication and superior-subordinate relationships in global project teams.

Apart from interviews, participant as well as non-participant observations were used to study the four cases. The aim of ethnographic fieldwork by means of participant observation is to show an empathic understanding of the daily activities of the employees, and to give the impression of having 'been there' (Czarniawska, 1998). In this way, daily staff activities are understood within their social, historical, cultural, political and economic contexts (Bate, 1997). During the fieldwork, all researchers were physically present on the work floor for an extended period, ranging from three to six months (see Table 1). They attended face-to-face meetings held by Dutch and Indian managers as well as employees; they listened in on conference calls and telephone conversations, ate lunches and participated in dinners, parties and informal weekend activities. Consequently, social relations were established that revealed detailed insights into cultural practices, which generated valuable information about cultural issues, such as the caste system, that had not been addressed in formal interviews. 
TABLE 1

DATA COLLECTION TECHNIQUES

\begin{tabular}{|c|c|c|c|c|}
\hline Instruments & IBM & Accenture & Atos Origin & Philips \\
\hline Name department & $\begin{array}{l}\text { Application } \\
\text { Management Services }\end{array}$ & $\begin{array}{l}\text { Accenture Technology } \\
\text { Services }\end{array}$ & $\begin{array}{l}\text { System } \\
\text { Integration }\end{array}$ & $\begin{array}{l}\text { Philips Business } \\
\text { Applicant Services }\end{array}$ \\
\hline Research period & Summer 2005 & Autumn 2005 & Spring 2006 & Spring 2007 \\
\hline $\begin{array}{l}\text { Primary Data } \\
\text { Collector }\end{array}$ & $\begin{array}{l}\text { Annemiek Garritsen } \\
\text { (fem.) }\end{array}$ & Maartje de Bont (fem.) & $\begin{array}{l}\text { Paul Hollander } \\
\text { (male) }\end{array}$ & Anouk Staal (fem) \\
\hline Access through & Partner at IBM & Husband at Accenture & Employee & Relative at Philips \\
\hline Interviews front & 25 in Amsterdam & 6 in Almere & 5 in Utrecht & 3 in Eindhoven \\
\hline Interviews back & $\begin{array}{l}4 \text { by telephone } \\
3 \text { in Amsterdam }\end{array}$ & 8 in Bangalore & 16 in Mumbai & 20 in Bangalore \\
\hline Time in front & 3 months & 2 months & 2 months & 2 months \\
\hline Time in back & - & 1 month & 1 month & 4 months \\
\hline Projects & 2 & 4 & 4 & 3 \\
\hline Project type & Application changes & $\begin{array}{l}\text { Support of processes } \\
\text { Software for production }\end{array}$ & $\begin{array}{l}\text { Application } \\
\text { changes }\end{array}$ & Application changes \\
\hline $\begin{array}{l}\text { Participant } \\
\text { observation }\end{array}$ & $\begin{array}{l}\text { Conference calls } \\
\text { Telephone calls } \\
\text { Chatting } \\
\text { Meetings }\end{array}$ & $\begin{array}{l}\text { Formal work activities } \\
\text { Informal activities in } \\
\text { front and back office } \\
\text { Visits }\end{array}$ & $\begin{array}{l}\text { Work } \\
\text { discussions } \\
\text { Diners } \\
\text { Events }\end{array}$ & $\begin{array}{l}\text { Town hall meeting } \\
\text { Board visit } \\
\text { Meetings }\end{array}$ \\
\hline $\begin{array}{l}\text { Documents, } \\
\text { websites, reports }\end{array}$ & $\begin{array}{l}\text { Global sourcing } \\
\text { documents } \\
\text { Access to intranet }\end{array}$ & $\begin{array}{l}\text { Policy reports on global } \\
\text { sourcing } \\
\text { Cultural training }\end{array}$ & $\begin{array}{l}\text { Formal } \\
\text { documents } \\
\text { Intranet }\end{array}$ & $\begin{array}{l}\text { Outsourcing } \\
\text { documents }\end{array}$ \\
\hline
\end{tabular}

Analysis of data. In view of the above, it must be noted here that the researcher's self is not separable from the interpretations and events in organization studies (Van Maanen, 1995). Moreover, Humphreys (2005) notes that self-reflexive personal vignettes, when incorporated into a methods discussion, can add authenticity to interpretations. Such a reflective narrative is included here. Two team members, Paul and myself, have been trained as engineers (M.Sc.) with a background in software development; Paul was actually working in one of the organizations studied. This professional background helped us to understand the cultural practices of software developers. Furthermore, all members of the research team were Dutch nationals and had, apart from myself, no prior experience in India. I had been working as a professional telecom engineer in Asia before this study was set up, and in that context I had visited India 12 times since 1981 for business and pleasure. In addition, I had conducted anthropologic fieldwork in India for six months in 1991. To overcome preconceived cultural notions concerning Indian employees, I trained the research team members on complexity in Indian organizations. Finally, in their preparations, team members had to read and analyse the pilot study's literature review on Indian management. 


\section{THE HYBRIDIZATION OF CULTURAL PRACTICES}

The Dutch front offices of IBM, Accenture, Philips and Atos Origin all promoted the synergy strategy as the formal cooperation strategy between Dutch front and Indian back offices. To support these strategies cross-cultural training, information on the intranet, newsletters and team managers' exchange programmes were executed. IBM for example, used newsletters to inform about cultural differences between Dutch and Indians. Both IBM and Atos Origin supplied training for 'cultural awareness' for employees in the Dutch front offices. At the website the formal strategy of IBM states that 'Cultural knowledge and skills are of great importance to optimize the cooperation' (IBM Intranet Amsterdam). Furthermore, Philips team leaders in Eindhoven went to cultural workshops given by Indian back office managers. As a final example, Accenture supplied access to the Internet site Globesmart and offered a free virtual training "Building Cross Cultural Awareness". However, in all examples given few of the interviewed employees actually knew about these cross-cultural products and even fewer had used one of the products. In contrast - or because of this - front office employees were optimistic about bridging cultural differences.

"I think a new business culture will be developed as we are globally collaborating with each other. I think the world is working towards one culture; a labour-culture. We have to grow towards one culture; America is dominant in this new common culture". (Interview with Philips employee Eindhoven)

This optimism is also reflected in the IBM's intranet document stating that: "Cultural differences are becoming smaller because Indian employees wanted to adapt themselves to the Western culture" (IBM Intranet document).

Employees of the Indian back offices of IBM, Accenture, Philips and Atos Origin were not as positive as their front office colleagues on the synergy strategy. Some informants feared that 'Indian culture' will be dominated by the 'Western culture'. One Indian Philips employee described these emotions:

"A lot of IT companies are coming to India and that is the reason why the culture is changing right now. Our culture is changing because Western companies don't respect our culture enough. Now Indians have very long working hours in the private sector, we are not used to that". (Interview with Philips employee Bangalore)

Others emphasised the ability of Indian employees to cope with cultural diversity as there are employees from many different religious and regional backgrounds. Sikhs, Muslims, Christians, Buddhist, Hindus all work next to each other in the Indian back office. Some stress the uniqueness of Indian culture and the need to be different:

"I think we must not be shy to be different from the West. I think it is a combination of both whenever we think we have to adapt we will do it but inherent. We must not be shy and present our way of doing things to the world". (Interview with Philips employee Bangalore) 
While Dutch front office employees deny any tension caused by the shift of work to India, Indian back office employees frequently mentioned job insecurity of Dutch employees in their daily cooperation. Back office employees related the job insecurity to experienced resistance.

"I felt a tension when I was in Eindhoven. People were feeling insecure about their job and probably therefore not very open or supportive. I know that a lot of employees in Eindhoven are contractors, so because they are not direct Philips employees they are even more tensed to lose their job" (Interview with Philips employee Bangalore)

Data collected from the four cases show that front and back office employees perceived four cultural themes to be problematic in the cooperation; time management, communication, handling conflicts, and management style. The dynamics and complexity of sense-making processes in the collaboration between employees of front and back offices of IBM, Accenture, Philips and Atos Origin were concentrated at these four cultural themes. The new practices at the interface of meaning exchange that emerged from the collaboration are discussed now.

\section{New Practices of Time Management}

There is a time difference between the Netherlands and India of 4,5 hours in winter and 3,5 hours in summer. Therefore, the time window, hours in which employees can directly work together, is limited to 3,5-4,5 hours. Furthermore, working times are much stricter with the Dutch project employees than with the Indian employees:

"An important difference is that, in the case of the Netherlands, people strictly work eight hours. And they planned their activities as they concentrate all the energy during that time and just go home, after that. (Interview with Atos Origin employee Mumbai)

As a result of these differences, new practices arise as Indian employees work till late in the evening to stretch this time window. However, this flexibility is not voluntary:

"Officially you work five days in a week but most work six. This is not a good culture. Ok, sometimes it is necessary. When the project is very critical. But they do it over and over again". (Interview with Atos Origin employee Mumbai)

"Pressure in our work depends upon the day; If Eindhoven gives us a lot of work we have to finish that on time; we can't say 'no' for various reasons. So tension is definitely there. The people who are working on that particular data will stay till late at night to finish it according to the requirements from Eindhoven". (Interview with Philips employee Bangalore)

Interestingly, some Dutch front office project workers admit that they use the time window strategically by incidentally stressing, in the Dutch afternoon, the importance of work to be finished. They know their Indian colleagues are still at work in the evening and are flexible and are willing to help. Working in the weekend is not an option for Dutch employees in contrast to their Indian colleagues who regularly work on Saturdays. "If it is really important, there is 
enough flexibility with Indians to ask them to stay longer. And in general they say yes". (Interview with Accenture employee Utrecht).

In these new practices power relations between front and back office employees are reflected. Back office employees perceive themselves as commissioners in charge of solving the client's IT problems. In contrast, front office employees want to have direct contact with customers. They perceive their Indian colleagues as suppliers. These power relations were especially reflected in the hybridization of practices around planning. The planning of activities and the control of deadlines were a major source of irritation and tension within the global projects. Indian project employees stressed the success of their CMMI (Capability Maturity Model Integrated) quality system. Dutch project employees perceived themselves as very structured and in control of the project's progress and perceived their Indian colleagues to be less structured in their time planning,

"We have direct contact with the client, so if the product isn't here, that we have direct problems. They are further away from the client; they have problems with us not with the client". (Interview with Atos Origin employee The Hague)

To solve problems around planning Accenture for example started a new two-weekly meeting. In these meetings project members of back and front offices were involved in the consultation with the client. In this way, both Dutch and Indian project employees had to give account on the progress. Front office employees at IBM and Accenture stated they included some extra time in the planning for extra margin. As a result, new practices in the collaboration of front and back office employees emerged in the feedback on possible time delays. Within teams it was becoming a practice to inform each other about time delays. Asking for priority to the activities needed most urgently was now becoming a new practice.

"My observation is that if a person in the Netherlands is asked by his project manager to do three things for which she has doesn't have the time, then the person asks a question to the project manager 'you want me to do this, this, this and I will not be able to complete it, tell me what is your priority'. Whereas people in India may not come back to the project manager when it is not possible. In case of the Netherlands it is very straightforward". (Interview with Accenture employee Bangalore)

These findings on planning and time management are supported by literature on Indian work practices. According to Sahay and Walsham (1997: 432) Indian employees perceive details as something to have no control over, as unpredictable variables not worth bothering oneself with. Therefore, according to Frazee (1998: 10) projects are not worked out in detail. Gopalan and Rivera (1997) related the Indian perspective on time and deadlines to the Hindu perspective on time as a circular concept of time in which the unfinished aspects of this life are being postponed to the next life. This influences the attitude towards time and deadlines. According to Anisya and Annamma (1994) the absence of time management and long term perspective in Indian organizations is an obstacle to become more efficient. Finally, Chatterjee and Pearson (2000: 645) state that time isn't felt as urgent in Indian organizations. 


\section{Communication: The Language Paradox}

Based upon the interviews and observations an interesting language paradox was found. An important reason for MNC's to outsource their IT development to India is the availability of English speaking specialists (Carmel \& Tija, 2005). However, understanding each other's English is one of the largest problems noted by both Dutch and Indian project employees in the studied global IT project teams. Pinto (2005) acknowledge that overcoming problems in the use of the English language are important hidden costs in offshoring. According to English trained Indian professionals the English vocabulary of Dutch employees is limited.

"Their English is not very fluent, it is not very articulated and good.[It] has Affect in the sense there was some delay in the processing, because sometimes, most of the times, I wasn't able to get the language...it actually impacted the work in terms of delay". (interview with IBM employee Bangalore)

According to the Dutch project employees the speed of speech and the pronunciation hinder fluent communication. The term 'Hinglish' is being referred to in the projects to determine this problem. Language problems occur most frequently with telephone calls and conference calls. Surprisingly, video conferencing was not used frequently as the costs were high and the transport speed of images (too) low. To overcome ambiguity in the interpretation of the spoken English language informants prefer to use email and chat sessions.

"It is easier to communicate through written sources, therefore our contact with Eindhoven is mostly done through email or chatting, this way we can both make our language understandable. When you speak to each other our different accents could cause misunderstanding. We Indians speak very fast and we address people in a different way. Dutch people speak English very slow". (interview with Philips employee Bangalore).

New practices in communication arose. In order to understand emails in the Dutch language, some Indian project members learned Dutch. They also used Dutch vocabulary in their mails. Some even made up a list of typical Dutch words and their (implicit) meaning. Dutch project employees were not trained in English and neither did they learn Hindi although it was noticed that Dutch project employees used Hindi words in their email and chats. But the chat sessions were not without problems:

"In the beginning I had much irritation about the way Indians treated us. In the morning they said 'hello (name) good morning' and then I replied 'hello'. If someone does this in the Netherlands then I expect him to come up with a problem. So I asked him 'why do you do that?' He replied 'I come to the office and say good morning to all people in the chat.' That is curious, but now I know". (Interview with Atos Origin employee The Hague)

Other practices that arose are asking questions and summarising conversations if you don't understand your colleague at the other side of the telephone line or in a chat session. Employees ask their colleagues to repeat their sentences and ask questions about the meaning given to words 
or expressions. Furthermore, employees summarized the content of the conversations in order to confirm their understanding of the discussed issues.

\section{Dealing with Conflicts and Negative Feedback}

Interestingly, hybridization took place between the directness of Dutch project employees and the politeness of Indian project employees. Dutch project employees and managers found it difficult to fully trust the judgements of their Indian colleagues. Especially, the Indian 'yes' was subject of ambiguity.

“'Yes..ok...' that is what they always tell you! But they don't mean, like we do, 'ok, I will fix it for you' or 'I will do it' but more like 'ok, I have heard you'. And that doesn't mean that they will do it or that they understand something of it". (Interview with IBM employee Amsterdam)

Pleasing your colleague or supervisor makes it for Indian project employees difficult to say no. To solve the interpretation problem Dutch project employees ask their counterparts whether it is an Indian or a Dutch "yes".

"I rather have him saying 'no' when I tell it should be finished that next week. And that he says 'no, that is not possible'. Then I'm very happy because he dares to say 'no'. And if I ask 'when can you finish' and he will reply 'ít will cost me a half week extra', well then I believe him much more than when he says ' $\mathrm{OK}$ ' in return on my first question" (Interview with Atos Origin employee The Hague)

The Indian perspective on conflict can lead to problems in cross-cultural cooperation as most western social communication is aimed at direct communication, a relative free expression of dissatisfaction and angriness (Sahay \& Walsham, 1997: 421). This attitude reflects the Indian avoidance of conflict and disharmony (Anisya \& Annamma, 1994; Fusilier \& Durlabhji, 2001: 232; Sahay \& Walsham, 1997: 421; Sinha \& Sinha, 1990: 709). Social networks are very important as they replace in many cases the formal communication channels (Sahay \& Walsham, 1997: 423). To save the relation a third person can also be asked to give criticisms (Frazee, 1998: 11). Criticisms are given in a subtle, indirect way.

"We come up with something like 'probably this could be done in a better way.' We usually don't do it to our clients; when they are wrong we don't say 'you are wrong'. It is not only with our clients, it is also in our day to day life, we never try to hurt somebody by saying you are wrong or this is not correct...." (Interview with Atos Origin employee Mumbai)

More difficult is the solving of conflicts or giving negative feedback to Indian colleagues. As one project manager explained:

"If I did something awfully bad, the Dutch people will tell you in your face "you have done this bad and you have to face repercussion". Indian manager will tell me in a different way. He would say "this thing could have done better if you do 
this-this-and this things... and it may have repercussions on your career". (Interview with Atos Origin employee Mumbai)

The Dutch directness is generally perceived as insulting by foreigners (Van Der Horst, 2001). In this case, the direct style of communication and giving feedback of front office employees is being perceived by their Indian colleagues in the team as blunt and impolite. New practices emerged as back office employees would immediately communicate insulting issues to all team members. According to their Indian colleagues, Dutch project employees do nothing to explain, soften, or justify their direct messages and neither do the Dutch appreciate the work done by Indian project employees. Indian project employees perceive this as confronting, insulting and disturbing for their relations with Dutch colleagues within the project. However, Indian project employees have learned by experience that the Dutch bluntness doesn't mean an offence.

"When they say something that is frank or blunt we take offence, we take it as insulting. Yes, maybe because that is one part of our culture. We don't supply back or fight. It took some time, but then we were aware of this point, that Dutch bluntness is there and that it doesn't mean offence. We immediately communicated this to all in the team. It is still not easy to get over that". (Interview with IBM employee Bangalore)

This sensitiveness is reflected in the practice of knowledge sharing in the project teams. The feedback on the presentation skills of an Indian expert was asked to be given on paper rather than in direct speech. In one of the Atos Origin projects feedback was organized through the Pandora's Box. A project employee explained:

"If you want to give feedback you write this down on a piece of paper and put it in the box. You have a free choice of putting your name on the paper. At the staff meeting the manager opens the box. Of course he must be filtering some offensive material but he does read most of it. And at the next meeting we discuss these issues". (Interview with Atos Origin employee Mumbai)

The majority of Dutch project employees know about the Indian sensitiveness on receiving critics. According to the Dutch interviewed, negative criticisms are given on actions and behaviour of a person which has nothing to do with the person itself. They try to minimize the impact of their direct behaviour by adapting their behaviour.

"I do try it sometimes, but when there is no understanding you have to be more direct. [...] I try to evade the question to a level that they can come up with the conclusion themselves. In this way I'm not direct and they think they have invented the wheel." (Interview with IBM employee in Amsterdam)

"Maybe if you approach a colleague, who is at the same level, preventing to lose one's face but at the same time experience a pressure to do something" (interview with Accenture employee Bangalore) 
Others give feed back in an indirect way as one Accenture employee Utrecht told us; "I first try to speak to the person himself. I tell him that it might be good to include another expert. I always hope that that is enough to get someone thinking".

\section{Hybridization of Management Style and Leadership Practices}

In the study, we have observed different attempts to create meaningful rituals and practices for both Dutch and Indian employees. At one example;

"An enormous stage was built in the middle of the floor and the Dutch board was invited to cut the traditional Indian cake, which consisted of several different layers. It was notable that all managers, Dutch and Indian, felt uncomfortable as they misunderstood each other while cutting the cake and handed the first piece of cake several times over and over to each other. Finally, a Dutch manager took the first piece". (observation during meeting Philips back and front office managers in Bangalore)

This observation is an example of the sensitive search for new management practices. Weekly conference calls and face to face meetings every three to four months were used to discuss management issues. A project manager in India is not only managing the project but is also responsible for the project members. The manager is a 'father' figure who takes care for the well being of the 'family' (Sahay \& Walsham, 1997). An Indian informant reflects upon the role of project manager:

"In India the project manager does not only manage the project, but also manages my people, I'm also the people manager of this project. I'm responsible for my peoples development also. That's different from what (...) does, he just manage the project". (Interview with IBM employee Bangalore)

The family care leadership style is called the nurturant-task leader (Gopalan \& Rivera, 1997: 167). A nurturant-task leader is someone who takes care of the employees, shows his feelings, shows personal intersest and is committed to the growth of the employees (Agarwal \& Misra, 1993; Gopalan \& Rivera, 1997). In return, a manager expects obedience and conformity by his people (Chatterjee \& Pearson, 2000). In contrast to this, a Dutch manager expects initiatives and assertive behaviour from his employees (Van Der Horst, 2001). In the eyes of one Indian employee:

"One big difference I notice with people from Holland is that they can go to their boss and tell him anything. He can tell him that he is stupid. That you give me this kind of work. It is not considered impolite or disrespect or refusal of work. I was surprised to see that. We are not brought up that way". (Atos Origin employee Mumbai)

According to Agarwal and Misra (1993) Indian employees prefer an authoritarian style of management in which choices, direction and policy is decided upon by the manager. Clear hierarchical relations are preferred in Indian organizations (Chatterjee \& Pearson, 2001: 645). Indian managements style is described as paternalistic (Anisya \& Annamma, 1994; Sahay \& 
Walsham, 1997). The paternalistic management style and hierarchical sensitiveness of Indian project employees is used strategically by the majority of Dutch employees. Connecting the right person at the right level can help solve an impasse and to get things done.

"If a team doesn't meet its deadline for a customer, I just call and make use of my hierarchical position by telling: 'you have to keep on working for seven days a week'. And if I'm connected to the correct manager over there, than it definitely will happen" (interview with Atos Origin employee The Hague)

Recent economic development has an impact on the value orientation of Indian professionals in organizations (Chatterjee \& Pearson, 2000). Increasingly complex structures of modern organizations develop in large Indian cities (Prins, 2004). Fusilier and Durlabhji (2001) show the enthusiasm of Indian managers to adapt to western management practices and to abandon the cast system. However, the cast system is still noticeable in the cooperation. According to a Dutch manager:

"A [Indian] customer of us descended from a family of higher caste than the family of my [Indian] boss. This man refused to communicate with my boss. He was willing to talk to me as I wasn't part of the cast system”. (interview with IBM employee Amsterdam)

According to Anisya and Annama (1994) the new trend of managers adapting to western management practices can result in dilemma's for the manager living with two distinct value orientations. Sahay and Walsham (1997) studied the value orientation of Indian managers and found that Indian managers internalised two distinct set of value orientations; the traditional values from family and community and the values from education and professional training. For Indian managers it is difficult to combine their traditional and modern roles (Chatterjee \& Pearson, 2000; Gopinath, 1998). During our field visits it was noticed that traditional family systems were still strongly influencing employees' daily lives.

"I am very pleased to share with you that I got engaged yesterday with xxx (My would be). Not with the same who was my girlfriend but with someone else because of the sake of our families...But I am very happy to accept the things in life and ready to enjoy me and my would-be future." (email of Accenture employee Bangalore)

\section{DISCUSSION: NEW PRACTICES IN GLOBAL IT PROJECTS}

Although in the studied cases the MITSP's formally all executed the synergy strategy, this is not completely reflected in the daily work practices of front and back office employees. Not many employees actually knew about this strategy and fewer attended a cross-cultural training. Ethnocentric strategies could be observed in both the front and back office. In the back office the uniqueness of the Indian culture and management style is emphasised. Front office employees emphasise their superior knowledge and their direct contacts with the client. Emphasising differences in status between Indian and Western IT employees has been noticed earlier (Levina \& Vaast, 2008). The fear of losing contact with the customers and losing highly qualified jobs to the 
Indian back offices is observed in all of the four cases. Fear for job insecurity was observed at the Indian back offices. In the Philips case $75 \%$ of the interviewed employees in Eindhoven thought it was not a good decision to set up a back office department in Bangalore.

"There is a strong belief that you can cut costs when you outsource to India. Now that we actually have established a back office there, I'm not totally sure about the truth of it. Monitoring and managing our Indian counterparts costs a lot of time and money; all our processes are delayed caused by bureaucracy over there. I think all our team leaders will prefer to work with European people". (interview with Philips employee in Eindhoven)

The cross-cultural cooperation within the geographically distributed IT projects is object and outcome of social interactions. In these interactions new practices have emerged from the interface between Dutch and Indian IT specialists in the studied projects (see table 2). The new cultural practices, which emerged from solving collaborative tensions, reflect the struggle for power between front and back offices.

\section{TABLE 2 \\ NEW PRACTICES IN THE CROSS-CULTURAL COOPERATION OF FRONT AND BACK OFFICE EMPLOYEES}

\begin{tabular}{ll}
\hline Cultural topics & New cultural practices \\
\hline Time management & Back office employees stretch time window by working later \\
& Back office employees informing front office employees about time delays \\
& Back-office employees ask for work prioritising \\
& Emphasising urgency late Friday afternoon by front office employees \\
& Two-weekly meetings with client, back and front office on planning \\
Communication & Using each other's language in communication \\
& Asking for the meaning of each other's words and concepts \\
& Listing the meaning of typical Dutch words and expressions \\
& Agreement on the meaning of Dutch or Indian 'yes' \\
Conflict solving & Stressing politeness in conversation \\
& Giving of feedback on paper in Pandora's box \\
& Strategic escalating conflicts by front employees \\
Management style & Stressing respect and conformity by back office employees \\
& Stressing initiatives and assertiveness by front office employees \\
& Using the hierarchical sensitiveness of back office employees \\
\hline
\end{tabular}

\section{CONCLUSIONS}

This paper moved away from cultural values research (Jackson \& Aycan, 2006) and focuses at the emergence of new cultural practices in the cooperation between Indian back office and Dutch front office employees in geographically distributed IT projects in Multinational IT Service Providers (MITSP). A business anthropological perspective was developed to study the four Multinational IT Service Providers IBM, Accenture, Philips and Atos Origin. The study found that all four companies used a synergy strategy to manage cultural interfaces between front and back offices. This is in line with the general notion that cultural differences can and will be 'bridged' or 'overcome' by giving advices and by training (Carmel \& Tija, 2005; Staples \& 
Zhao, 2006). It is assumed that in time, the high initial costs of coordination will decrease as Indian back offices will adapt to 'Western' cultural practices. However, the results of the study show that the success of these synergy strategies has to be questioned as the unequal power balance between front and back offices triggered the situational construction of cultural differences.

Taken together, these results suggest that traditional functionalist and instrumental project management approaches as well as traditional multi-value models have so far failed to provide sufficient insight into the situational construction of cultural differences in global IT projects. Salient cultural issues in global projects may differ surprisingly from the cultural issues that multi-value models would lead us to expect. Furthermore, managers need knowledge on these social processes and cultural arrangements to successfully manage global projects; managers and employees in global projects need to learn not only about the 'other' but, foremost, to become more culturally and politically sensitive. In addition, they should learn to understand how their own behaviour is interpreted by the 'other', given (a)symmetric power relations. Managers and employees will thus be better equipped to successfully handle difficulties and promises of cooperation in global IT projects.

Such a dynamic, interpretative perspective of cross-cultural management is the field for business anthropologists. They include power issues, hybridization and situational behaviour in their studies and consultancy on cross-cultural management. Equipped with such a perspective, in this study on MITSP's is has been shown that increasingly Indian organizations and back offices (want to) take control over direct client contacts, develop products and services and be involved in high end software development. Dutch front office employees are afraid to lose jobs and interesting work to Indian back office employees. The power struggle is reflected in the new practices that emerged to deal with different perceptions of working hours and meaning given to deadlines. Indian back office employees have to be more flexible and work longer hours to stress the time window. Dutch project employees used the 'Indian flexibility' and strategically use hierarchical sensitiveness to put pressure on back office employees to get things done the same day or during the weekend.

Therefore, collaborative cross-cultural learning therefore has to be understood in its power context. Front office employees, afraid of losing high qualified jobs, stress the low quality of planning, time management and bureaucracy of their Indian back office colleagues. Emphasising one's own cultural practices to gain direct access to clients or to increase the office status does not result in bridging cultures. The assumption that both front and back office cultures will grow towards one culture is therefore questionable. The organizations studied in this paper are not new in offshoring and have extended cross-cultural experiences. The expectation is that the so-called hidden costs in offshoring therefore will remain to be high (Pinto, 2005).

\section{REFERENCES}

Adler, N. (1986). International dimensions of organisational behaviour, Boston: Kent publishers.

Agarwal, M., \& Misra, G. (1993). Socio-cultural Values and Relative Deprivation in Work Organisations. Indian Journal of Industrial Relations, 28, 327-340. 
Ailon-Souday, G., \& Kunda, G. (2003). The Local Selves of Global Workers: The Social Construction of National Identity in the Face of Organizational Globalization. Organization Studies, 24(7), 1073-1096.

Anisya, T. S., \& Annamma, P. (1994). India; Management in an ancient and modern civilization. International Studies of Management and Organization, 24(1), 91-105.

Bate, P. (1997). Whatever Happened to Organizational Anthropology? A Review of the Field of Organizational Ethnography and Anthropological Studies. Human Relations, 50(9), 1147-1171.

Brannen, J. V., \& Salk, J. E. (2000). Partnering across borders: Negotiating organizational culture in a German-Japan joint venture. Human Relations, 53(4), 451-487.

Budhwar, P. S., \& Sparrow, P. R. (2002). Strategic HRM through the cultural looking glass: mapping the cognition of British and Indian managers. Organisation Science, 23(4), 599-638.

Budhwar, P. S., Varma, A., Singh, V., \& Dhar, R. (2006). HRM systems of Indian call centres: an exploratory study. International Journal of Human Resource Management, 17(5), 881-897.

Carmel, E. (1999). Global Software teams: Collaborating Across Borders and Time Zones, Essex: Prentice Hall.

Carmel, E., \& Tija, P. (2005). Offshoring Information Technology, Cambridge: University Press.

Chatterjee, S. R., \& Pearson, C. A. L. (2000). Indian managers in transition: Orientations, work goals, values and ethics. Management International Review, 40, 81-95.

Chatterjee, S. R., \& Pearson, C. A. L. (2001). Perceived societal values of Indian managers; some empirical evidence of responses to economic reform. International Journal of Social Economics, 28(4), 368-379.

Chevrier, S. (2003). Cross-cultural management in multinational project groups. Journal of World Business, 38, 141-149.

Clausen, L. (2007). Corporate Communication Challenges: A 'Negotiated' Culture Perspective. International Journal of Cross Cultural Management, 7(3), 317-332.

Czarniawska, B. (1992). Exploring Complex Organizations. A Cultural Perspective, London: Sage.

Dafoulas, G., \& Macaulay, L. (2001). Investigating Cultural Differences in Virtual Software Teams. The Electronic Journal on Information Systems in Developing Countries, 7(4), 1-14.

Frazee, V. (1998). Working with Indians. Workforce, 3(4), 1-14. 
Fusilier, M., \& Durlabhji, S. (2001). Cultural values of Indian managers: An exploration through unstructured interviews. International Journal of Value-based Management, 14(3), 223-236.

Gao, G. (2011). The Effects of Intercultural Training upon the Organizational Performance of Municational Corporations in China. International Journal of Business Anthropology, 2(1), 97 116.

Gopalan, S., \& Rivera, J. B. (1997). Gaining a perspective on Indian value orientations:

implications for expatriate manager. International Journal of Organizational Analysis, 5(2), 156179.

Gopinath, C. (1998). Alternative approaches to indigenous management in India. Management international review, 38(3), 257-275.

Hall, E. T. (1976). Beyond Culture, New York: Double day/Anchor Books (1981).

Hannerz, U. (1992). Cultural Complexity. Studies in the Social Organization of Meaning, New York.: Columbia University Press.

Hasting, C. (1995). Building the culture of organisational networking. International Journal of Project Management, 13(259-263).

Hodgson, D. E., \& Cicmil, S. (Eds.). (2006). Making Projects Critical. New York: Palgrave McMillan.

Hofstede, G. (1980). Culture's Consequences: International Differences in Work-Related Values, London: Sage Publications.

Holden, N. (2002). Cross-cultural management. A knowledge management Perspective, Essex: Prentice Hall.

Jackson, T., \& Aycan, Z. (2006). Editorial: From cultural values to cross cultural interfaces. International Journal of Cross Cultural Management, 6(1), 5-13.

Jacob, N. (2005). Cross-cultural investigations: emerging concepts. Journal of Organisational Change Management, 18(5), 514-528.

Jenkins, R. (2004). Social Identity (second ed.), London: Routledge.

Kakar, S., Kakar, S., KetsdeVries, M. F. R., \& Vrignaud, P. (2002). Leadership in Indian Organizations from a Comparative Perspective. International Journal of Cross Cultural Management, 2(2), 239 - 250.

Krishna, S., Sahay, S., \& Walsham, G. (2004). Managing cross-cultural issues in global software outsourcing. Communications of the ACM, 47(4), 62-66. 
Levina, N., \& Vaast, E. (2008). Innovating or Doing as Told? Status Differences and Overlapping Boundaries in Offshore Collaboration. MIS Quarterly, 32(2), 307-332.

Lowe, S. (2002). The Cultural Shadows of Cross Cultural Research: Images of Culture. Culture and Organisation, 8(1), 21-34.

Lowe, S., Moore, F., \& Carr, A. N. (2007). Paradigmapping Studies of Culture and Organization International Journal of Cross Cultural Management, 7, 237-251.

Martin, J. (2002). Organizational culture : mapping the terrain (2nd print ed.), Thousand Oaks, Calif., etc.: Sage Publications.

Matloff, N. (2005). Offshoring: What Can Go Wrong? IT Professional, 7(4), 39-45.

Morden, T. (1999). Models of National Culture - Management Review. Cross Cultural Management, 6(1), 19-44.

Nicholson, B., \& Sahay, S. (2001). Some political and cultural issues in the globalisation of software development: case experience from Britain and India. Information and Organization $11,25-43$.

Peterson, M. F. (2007). The Heritage of Cross Cultural Management Research: Implications for the Hofstede Chair in Cultural Diversity. International Journal of Cross Cultural Management, 7(3), 359-377.

Pinto, J. A. M. (2005). Swimming Against the Tide: The Hidden Costs of Offshoring. The CPA Journal, 75(1), 9-11.

Prins, F. (2004). Western Management in India, Leiden: Leiden University Press.

Sackmann, S. A., \& Friesl, M. (2007). Exploring cultural impacts on knowledge sharing behavior in project teams - results from a simulation study. Journal of Knowledge Management, 11(6), 142-156.

Sackmann, S. A., \& Phillips, M. E. (2004). Contextual Influences on Cultural Research: Shifting Assumptions for New Workplace Realities. International Journal of Cross Cultural Management, 4(3), 370-390.

Sahay, S., Nicholson, B., \& Krishna, S. (2003). Global IT Outsourcing: Software Development Across Borders, Cambridge: University Press.

Sahay, S., \& Walsham, G. (1997). Social Structure and managerial agency in India. Organization Studies, 18(3), 415-444.

Sapra, C. L. (1995). Managing the Indian economy in the cross-cultural context. Cross Cultural Management: An International Journal, 2(2), 38 - 41. 
Schneider, S., \& Barsoux, J.-L. (1997). Managing across-cultures, London: Prentice Hall.

Schwartzman, H. B. (1993). Ethnography in Organizations, (Vol. 27), Newbury Park: Sage Publications, Inc.

Sen, A. (2005). The Argumentative Indian. Writing on Indian Culture, History and Identity, New Delhi: Penguin Books.

Shimoni, B. (2008). Separation, emulation and competition: Hybridization styles of management cultures in Thailand, Mexico and Israel. Journal of Organizational Change Management, 21(1), $107-119$.

Shimoni, B., \& Bergmann, H. (2006). Managing in a Changing World: From Multiculturalism to Hybridization - The Production of Hybrid Management Cultures in Israel, Thailand and Mexico. Academy of Management Perspectives, 20(3), 76-89.

Singh, J. P. (1990). Managerial culture and work related values in India. Organization Studies, 11(1), 75-106.

Sinha, J. B. P., \& Sinha, D. (1990). Role of social values in Indian organizations. International Journal of Psychology, 25(5-6), 705-714.

Söderberg, A., \& Holden, N. (2002). Rethinking Cross Cultural Management in a Globalizing Business World. International Journal of Cross Cultural Management, 2(1), 103-121.

Staples, D. S., \& Zhao, L. (2006). The Effects of Cultural Diversity in Virtual Teams Versus Face-to-Face Teams. Group Decision and Negotiation, 15(4), 389-406.

Tian, R. G., Lillis, M. P., \& Van Marrewijk, A. H. (2010). General Business Anthropology, Miami: North American Business Press.

Trompenaars, F. (1993). Riding the waves of Culture. Understanding cultural diversity in business, London: The Economist Books Ltd.

van der Horst, H. (2001). The Low Sky. Understanding the Dutch, Schiedam: Scriptum.

Van Marrewijk, A. H. (2004). The Management of Strategic Alliances: Cultural Resistance. Comparing the Cases of a Dutch Telecom Operator in the Netherlands Antilles and Indonesia. Culture and Organization, 10(4), 303-314.

Van Marrewijk, A. H. (2007). Managing project culture: The case of Environ Megaproject. International Journal of project management, 25(3), 290-299.

Van Marrewijk, A. H. (2010). Situational Construction of Dutch - Indian Cultural Differences in Global IT Projects. Scandinavian Journal of Management, 26(4), 368-380. 
Virmani, B. R. (2007). The Challenges of Indian Management, New Delhi: Response Books.

Weick, K. E. (1995). Sensemaking in Organizations, London: Sage.

Yanow, D., \& Schwartz-Shea, P. (Eds.). (2006). Interpretation and Method: Empirical Research Methods and the Interpretative Turn. Armonk, New York: M E Sharpe.

Yin, R. (2003). Case Study Research Design and Methods, London: Sage Publications.

Zwikael, O., Shimuzu, K., \& Globerson, S. (2005). Cultural differences in project management capabilities: A field study. International Journal of Project Management, 23(6), 454-462. 